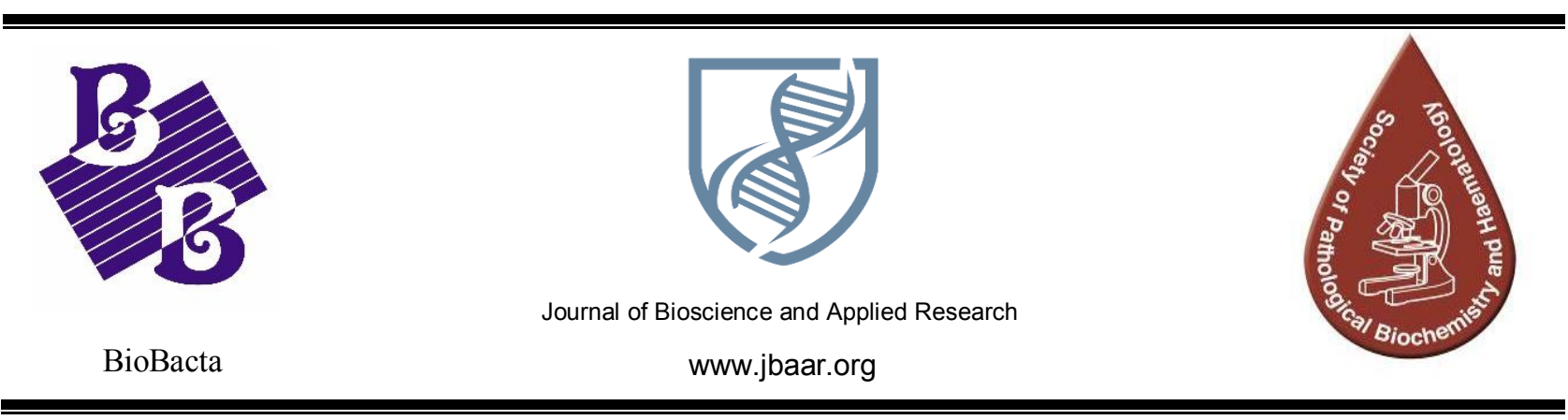

\title{
Molecular screening of Helicobacter pylori among Egyptian patients with decompensated liver cirrhosis
}

\author{
Mohamed Y. Nasr' ${ }^{1}$, Ehsan Hassan², Ghada Hassan' ${ }^{\text {, Asmaa Ibrahim }}{ }^{3}$, Salwa. E. Mohamed ${ }^{1}$, \\ Amal Abdel-Aziz ${ }^{1}$ \\ 1. Genetic Engineering and Biotechnology Research Institute, University of Sadat City (GEBRI, USC), Egypt \\ 2. National Hepatology and Tropical Medicine Research Institute, Cairo, Egypt \\ 3.Diagnostic and Research Unit of Parasitic Diseases (DRUP), Department of Medical Parasitology, Kasr Al-Ainy \\ Faculty of Medicine, Cairo University, Cairo, Egypt
}

Corresponding Author: Asmaa Ibrahim*

E.mail: chemistasmaain@gmail.com

ORCID: 0000-0001-8119-9549

\begin{abstract}
Background: Globally Helicobacter Pylori (H. Pylori) infection and liver diseases are renowned with their high incidence rate. Recent studies have observed the relation between $H$. Pylori infection and liver disease progression to cirrhosis. This study aimed to determine the prevalence of $H$. pylori in liver cirrhotic patients. Patient and Methods: This study was conducted on 100 liver cirrhotic patients to detect $H$. Pylori infection based on UreA gene detection in ascites using nested polymerase chain reaction (nPCR). Biochemical analysis was performed on ascitic fluid, serum, complete blood count (CBC), and polymorph nuclear leukocytes count (PMN). Result: H. Pylori infection was detected in $75 \%$ of patients with liver cirrhosis. In ascitic fluid, H. pylori infection showed a highly significant association with albumin and $\mathrm{PMN}(\mathrm{P}=0.0001)$ and also with other biochemical analyses including serum ascites albumin gradient (SAAG), specific gravity, and glucose $(\mathrm{P}=0.005,0.0031$, and 0.02 , respectively). In serum only, the infection showed significant association with alkaline phosphatase, albumin, and hemoglobin with $\mathrm{P}$ values of $0.008,0.014$, and 0.008 , respectively. Conclusion: The current study results shed light on the significant role of H. Pylori infection in ascites of patients with decompensated end-stage liver cirrhosis suggesting a prospective relation between $H$. pylori infection and liver diseases progression due to hepatic infections especially HCV.
\end{abstract}

Key words: $H$. pylori, Nested PCR, UreA gene, Liver cirrhosis, HCV 


\section{Introduction}

Helicobacter pylori is a slow-growing, microaerophilic, highly motile, a gram-negative spiral bacterium. In developed countries, infection with this type of bacteria reached $50 \%$, while in developing countries, infections may reach 90\% (Mitchell and Katelaris. 2016). H. Pylori infection closely correlates with chronic gastritis, peptic ulcer, gastric carcinoma, and malignant lymphoma of gastric mucosa related lymphoid tissue (MALTOMA). In addition, it has been recognized as a class I carcinogenic factor by WHO. This type of bacteria may cause extragastric organ disturbances including aggravate cardiovascular diseases and metabolic diseases and affect the liver functions, especially in patients with liver cirrhosis (Waluga et al., 2015). Molecular methods are vastly used for diagnosing $H$. pylori infection for analyses of variance and studying the virulence and resistance patterns (Cirak et al., 2007). However, the high level of genomic plasticity between $H$. pylori different strains complicates the choice of target genes. Diversity of genes such as cagA, ureC $(g \operatorname{lm} M)$, ureA , 16S rRNA, and 26-kDa speciesspecific antigen (SSA) genes have been used as targets (Lage et al., 1995). UreA gene was used as a target in several studies due to its good sensitivity and specificity (Uribe et al., 1998 and Kawamata et al., 1996).

Hepatitis $\mathrm{C}$ virus (HCV) is the most prevalent infectious agent of hepatic diseases. It has severe complications varying from chronic inflammatory diseases, hepatic cirrhosis, and end-stage liver diseases to hepatocellular carcinoma (HCC) (Butel et al., 2007). Egypt has a high prevalence of $\mathrm{HCV}$ where it is recognized to be the main cause of high morbidity and mortality caused by liver diseases (El-Zanaty and Way 2008). Cirrhosis is scarring of the liver where the normal liver tissue is damaged and replaced with regenerated hepatic nodules surrounded by fibrous tissue septa. Cirrhosis eventually develops in 0 to $50 \%$ of patients with chronic HCV and HBV infection; however, it is not clear why only a proportion of patients with these infections progress to end-stage disease or by what mechanisms HCV-related cirrhosis may ultimately lead to HCC. Moreover, cirrhosis is the final common stage in patients with progressive liver diseases of various causes. It is recognized as the leading cause of death in people between the ages of 25 and 64 years (Kung et al., 2008).

Bacterial infections in patients with end-stage liver diseases affect their candidacy for liver transplantation as up to one-third of all hospitalized patients with cirrhosis are infected with sepsis (Fernandez et al., 2012 and Merli et al., 2010) which increases their mortality rate to more than 50\% (Olson et al., 2011). With regard to liver diseases, H. pylori infection has been reported in the liver tissue by detecting its DNA suggesting that these bacteria could be participating in the progression of the disease to cirrhosis and HCC (Ponzetto et al., 2000). The association between $H$. pylori and liver diseases has been observed but remains unknown (Waluga et al., 2015). The incidence of $H$. pylori or Helicobacter species infection was reported in patients with various liver diseases (Esmat et al., 2012 and Pirouz et al., 2009).

The main objective of the present study is to determine the prevalence of $H$. pylori infection among Egyptian patients with decompensated liver cirrhosis by using nested PCR targeting the UreA gene in ascites.

\section{Patients \& methods}

\subsection{Study design \& individuals}

This prospective cross-sectional study was conducted on Egyptian patients with end-stage chronic liver disease who were referred to the Hepatology and Tropical Medicine Research Institute, Al-Kasr Al-Ainy Faculty of Medicine, Cairo University for liver work-ups from March 2016 to May 2017. Clinical and laboratory parameters including etiology of cirrhosis, sex, age, liver function tests, and complete blood count were assessed at the baseline (date of paracentesis and/or endoscopy). 


\subsection{Sample Collection}

Venous blood samples were collected by plastic disposable syringes. After centrifugation, the resulted sera stored immediately at $-20^{\circ} \mathrm{C}$ until use. Ascites fluid was obtained by abdominal paracentesis in the first 24 hours after admission of patients using aseptic techniques according to

\section{Runyon 1986.}

\subsection{Biochemical and molecular analysis}

The serological and biochemical analyses were conducted on both serum and ascites fluid in the Clinical Pathology Department, Al-Kasr Al-Ainy Faculty of Medicine, Cairo University, while the molecular analysis was performed at the Lab of Molecular Medical Parasitology (LMMP) at the same faculty. The Research Ethics Committee of the faculty approved the study and informed consent was obtained from the study participants. Sera samples of the study patients were analyzed for albumin, total protein, bilirubin, creatinine, glucose, alkaline phosphatase, ALT, and AST, and the whole blood samples were analyzed for $\mathrm{CBC}$ and PMN using dialysis kit (Diagnostic Systems international Mc15, Cat. No.1224, Germany) kinetic method according to the manufacturer's instructions. Ascites fluid samples were analyzed for albumin, protein, SAAG, glucose, and specific gravity. Albumin concentration in the serum and ascitic fluid was determined according to Bakker and Mücke 2007, albumin concentration in serum and fluid is determined according to these factors: Serum protein concentration, Differentiation between serum albumin and ascitic fluid albumin, Serum glucose concentration (Bakker and Mücke 2007) and specific gravity (Light 1979).

\subsection{Molecular assay}

\subsubsection{Genomic DNA extraction}

Genomic DNA was extracted from the ascitic fluid using Zymo research spin columns, isolation mini kit (cat. no D 3024) according to the manufacturer's instructions. The extracted DNA was stored at $-20{ }^{\circ} \mathrm{C}$ until use.

\subsubsection{Nested Polymerase Chain Reaction (nPCR) for $H$. Pylori}

Nested PCR was performed with Helicobacter genus-specific UreA primers and it included a twosquinted PCR reaction. The first amplification was carried out in a final volume of $25 \mu$ l reaction mixture containing: DNA and the primers $2 \mathrm{~F} 2$ 5'ATATTATGGAAGAAGCGAGAGC-3' and 2R2 5'ATGGAAGTGTGAGCCGATTTG-3'. The second reaction amplified by internal sets $2 \mathrm{~F} 3$ (IF) 5'CATGAAGTGGGTATTGAAGC-3 and 2R3 (IR) 5'AAGTGTGAGCCGATTTGAACCG-3'. The amplification conditions were as follows: 35 cycles of $1 \mathrm{~min}$ at $96^{\circ} \mathrm{C}$ (denaturation), $1 \mathrm{~min}$ at $57^{\circ} \mathrm{C}$ (annealing), $1.5 \mathrm{~min}$ at $72^{\circ} \mathrm{C}$ (extension). Amplification was obtained according to Sasaki $\boldsymbol{e t}$ al., 1999. The amplified products were analyzed by $1.5 \%$ agarose gel electrophoresis with ethidium bromide at $100 \mathrm{~V}$ for $30 \mathrm{~min}$. The band of gels was viewed under ultraviolet light.

\subsection{Statistical analysis}

All statistical calculations were done using computer program IBM SPSS (Statistical Package for the Social Science; IBM Corp, Armonk, NY, USA) release 22 for Microsoft Windows. Data were statistically described in terms of mean, standard deviation (SD), median and range, or frequencies (number of cases) and percentages when appropriate. A comparison of the numerical variables between the study groups was done using Student's $t$-test for independent samples in comparing normally distributed data and Mann Whitney $U$ test for independent samples in comparing non-normal data. For comparing categorical data, Chi-square $\left({ }^{2}\right)$ test was performed. The exact test was used instead when the expected frequency is less than 5 . P values less than 0.05 were considered statistically significant.

\section{Results}

\subsection{Determination of infection with $\boldsymbol{H}$. pylori}

The demographic and laboratory data of the 100 patients included in this study were summarized in Table 1. The mean age of patients was $58 \pm 9$. The majority of patients were males (68). H. pylori DNA was detected in $75 \%$ of the included patients using Helicobacter genus-specific UreA gene primers 
(Fig. 1). The infection incidence rate was higher difference was not statistically significant. among males than females $(69.3 \%)$; however, this

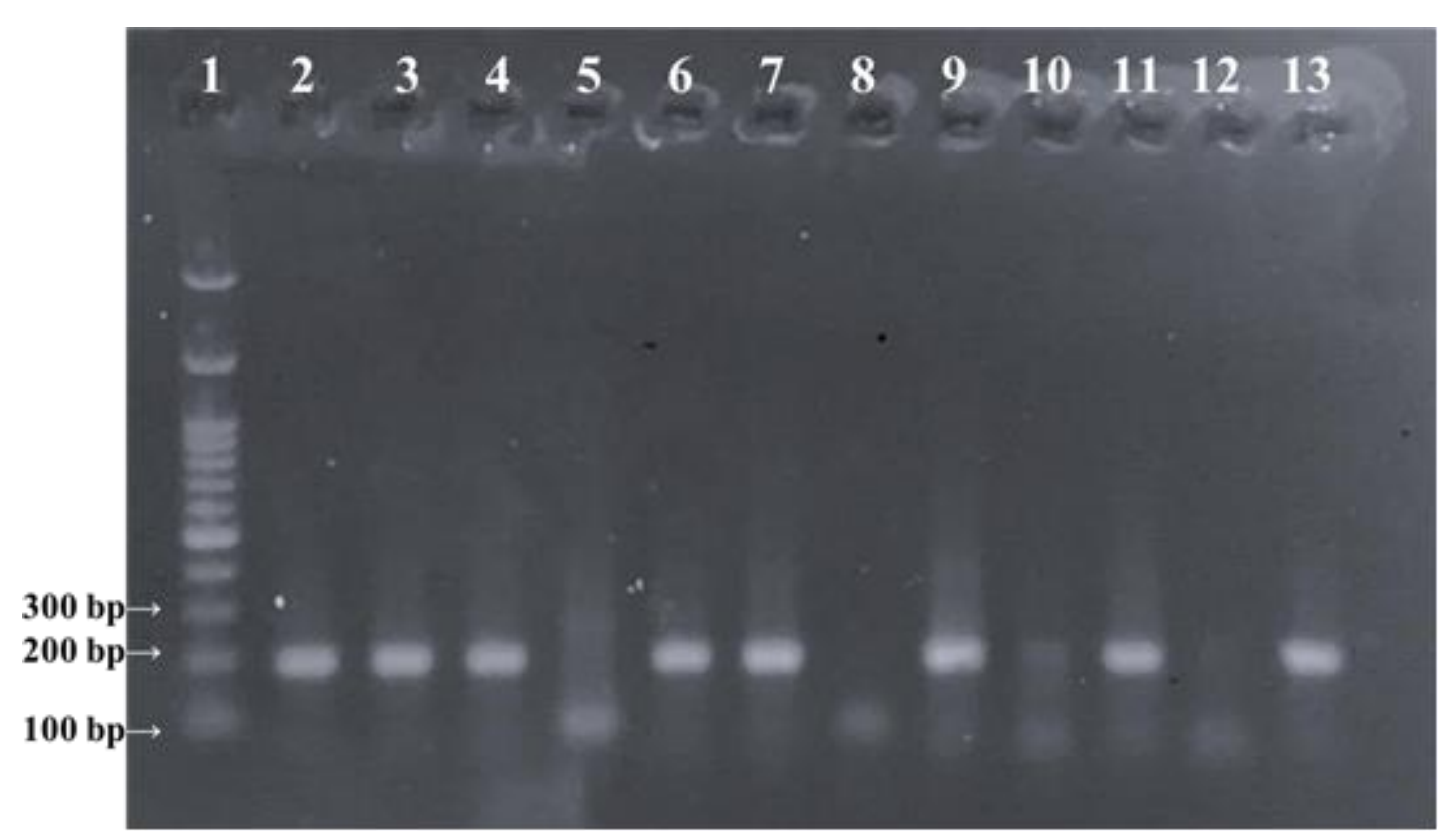

Figure1: Agarose gel electrophoresis for the products of the nPCR targeting UreA gene of H.pyloriat (200bp). Lane 1: 100 bp "ladder". Lanes 2-4, 6, 7, 9 \& 11: Positive samples. Lanes 5, 8 \& 10: Negative samples. Lane 12: Negative control. Lane 13: Positive control.

Table 1: Demographic and clinical characteristics of tested sero-positive patients

\begin{tabular}{lcc}
\hline & $\begin{array}{c}\text { Tested group } \\
\text { (no:100) }\end{array}$ & P value \\
\hline Age (years) & mean \pm SD & $\mathbf{0 . 0 2 *}$ \\
\hline sex & $58 \pm 9$ & $\mathbf{0 . 7 9 4}$ \\
\hline male & $68(68 \%)$ & \\
\hline female & $32(32 \%)$ & $\mathbf{0 . 2 8 4}$ \\
\hline HB $($ gms/dL) & $9.7 \pm 1.9$ & $\mathbf{0 . 4 4 7}$ \\
\hline TLC $($ cells/mcL) & $5.7 \pm 2.1$ & $\mathbf{0 . 9 3 4}$ \\
\hline Platlets $(\mathrm{Platlets} / \mathrm{mcL})$ & $106 \pm 42.8$ & $\mathbf{0 . 0 9 8}$ \\
\hline Bilirubin(mg/dl) & $2 \pm 1.7$ & $\mathbf{0 . 2 9 5}$ \\
\hline ALT(U/L) & $51 \pm 34.9$ & $\mathbf{0 . 4 5 9}$ \\
\hline AST(U/L) & $59.5 \pm 31.9$ & $\mathbf{0 . 2 3}$ \\
\hline ALP(U/L) & $162 \pm 104$ & $\mathbf{0 . 3 9 4}$ \\
\hline Albumin(gms/dl) & $2.8 \pm 0.5$ & $\mathbf{0 . 5 6 3}$ \\
\hline Creatinin(mg/dl) & $1.2 \pm 0.6$ & $\mathbf{0 . 7 8 2}$ \\
\hline B.Sugar(mg/dl) & $146 \pm 59$ & \\
\hline
\end{tabular}

Data presented as mean $\pm \mathrm{SD}$, with $\left(^{*}\right) P$ value $<0.05$ is significant. 
3.2. Comparison of liver functions between patients with and without $H$. Pylori infections

The comparisons between levels of liver enzymes in patients with and without $H$. pylori infection were performed in both sera and ascitic fluid and summarized in Tables 2 and 3. Among the results, albumin and PMN showed a highly significant association $(\mathrm{P}=0.0001)$ with $\mathrm{H}$. pylori infection. Albumin was higher in $H$. pylori-negative cases than in positive cases (negative correlation) (Fig. 2), while PMN was higher in $H$. pylori-positive cases than in negative ones (positive correlation) (Fig. 3). Moreover, other variables such as SAAG, specific gravity, glucose, and alkaline phosphatase showed a significant positive association with $H$. pylori infection, while hemoglobin showed a negative association with it (Table 2 and 3).

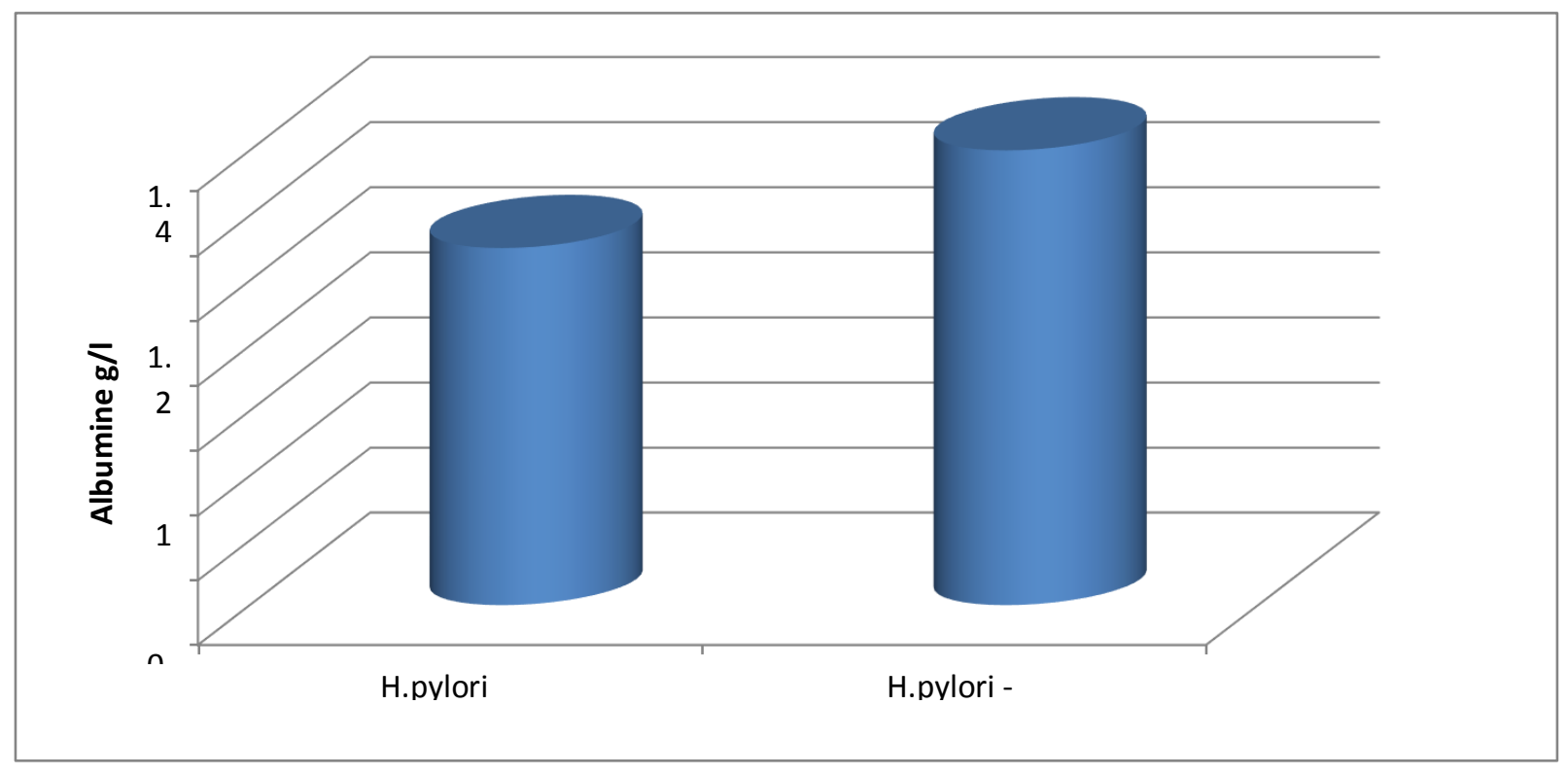

Figure (2): serum albumin (g/dl) between H.pylori +ve and H.pylori -ve groups

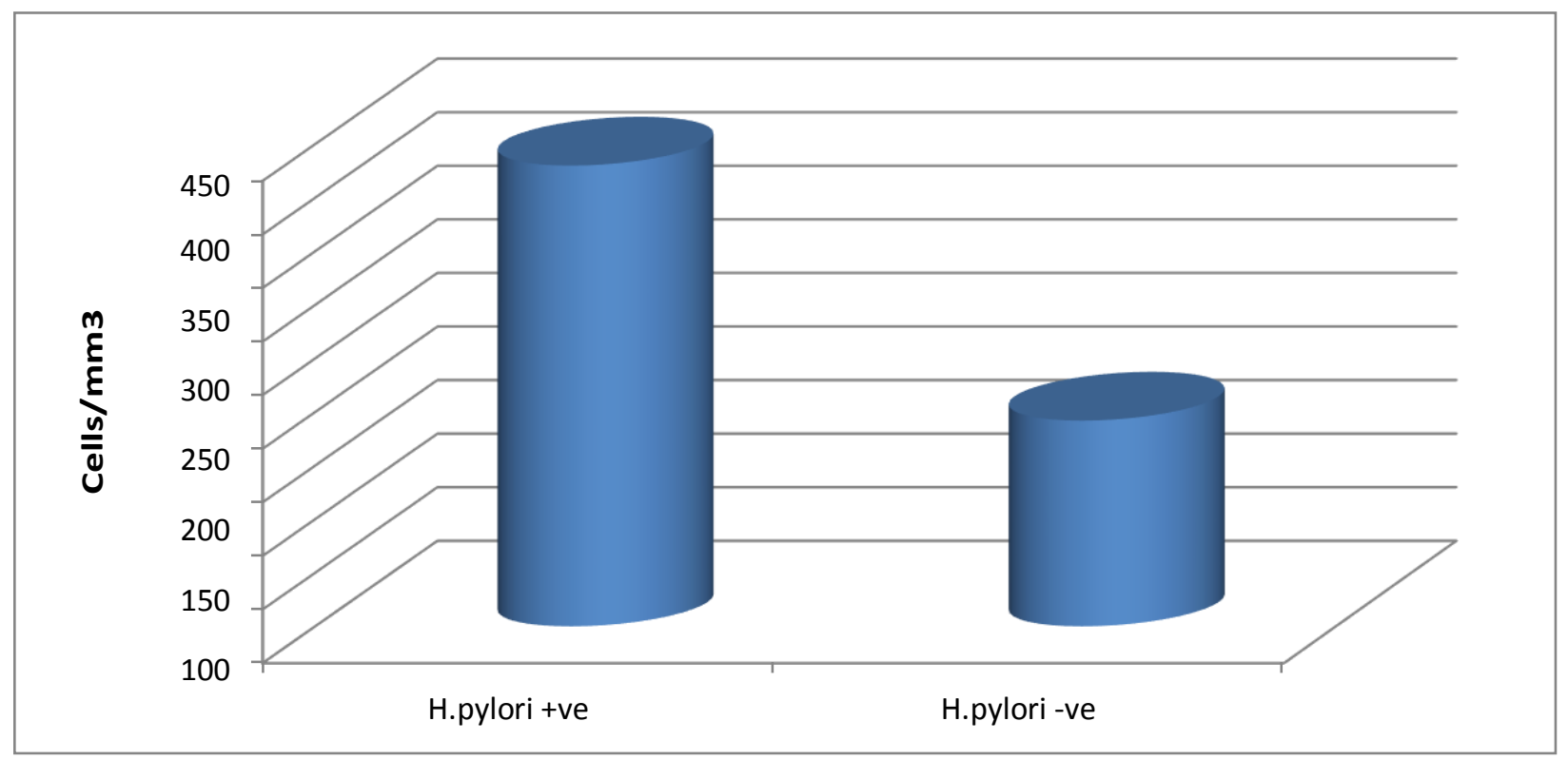

Figure (3): PMN (cells $/ \mathrm{mm}^{3}$ ) between H.pylori +ve and H.pylori -ve groups 
Table 2: Serological and biochemical analyses association with H. Pylori infection

\begin{tabular}{lccc}
\hline Variable & $\begin{array}{c}\text { H.pylori +ve group } \\
\text { (no:75) }\end{array}$ & $\begin{array}{c}\text { H.pylori -ve group } \\
\text { (no:25) }\end{array}$ & P value \\
\hline & mean \pm SD & mean \pm SD & \\
\hline HB $(\mathrm{gms} / \mathrm{dL})$ & $9.9 \pm 1.8$ & $8.8 \pm 1.9$ & $\mathbf{0 . 0 0 8}^{*}$ \\
\hline TLC $(\mathrm{cells} / \mathrm{mcL})$ & $5.7 \pm 2.2$ & $5.5 \pm 2.1$ & $\mathbf{0 . 5 3 6}$ \\
\hline Platlets $(\mathrm{Platlets} / \mathrm{mcL})$ & $106 \pm 40.4$ & $112 \pm 50$ & $\mathbf{0 . 4 6 6}$ \\
\hline Bilirubin(mg/dl) & $1.93 \pm 1.92$ & $1.5 \pm 1.2$ & $\mathbf{0 . 0 6 3}$ \\
\hline ALT(U/L) & $52 \pm 36$ & $47 \pm 29$ & $\mathbf{0 . 3 3 3}$ \\
\hline AST(U/L) & $58 \pm 31$ & $53 \pm 32$ & $\mathbf{0 . 3 9}$ \\
\hline ALP(U/L) & $157 \pm 111$ & $110 \pm 57$ & $\mathbf{0 . 0 0 8}$ \\
\hline Albumin $(\mathrm{gms} / \mathrm{dl})$ & $2.8 \pm 0.5$ & $3 \pm 0.4$ & $\mathbf{0 . 0 1 4}$ \\
\hline Creatinin $(\mathrm{mg} / \mathrm{dl})$ & $1.2 \pm 0.7$ & $1.1 \pm 0.5$ & $\mathbf{0 . 3 1}$ \\
\hline B.Sugar $(\mathrm{mg} / \mathrm{dl})$ & $145 \pm 58$ & $141 \pm 60$ & $\mathbf{0 . 6 5 5}$ \\
\hline
\end{tabular}

Data presented as mean $\pm \mathrm{SD}$, with $(*) P$ value $<0.05$ is significant.

Table 3: Correlation between ascitic fluid analysis and $H$. pylori infection

\begin{tabular}{lc}
\hline Variable & All study population \\
\hline & mean \pm SD \\
\hline Albumin $(\mathrm{gms} / \mathrm{dl})$ & $\mathbf{2 . 8} \pm \mathbf{0 . 5}$ \\
\hline SAAG & $\mathbf{1 . 5} \pm \mathbf{0 . 5}$ \\
\hline S.gravity & $\mathbf{1 . 4} \pm \mathbf{0 . 7}$ \\
\hline Total Protein $(\mathrm{gms} / \mathrm{dL})$ & $\mathbf{2 . 6} \pm \mathbf{0 . 8}$ \\
\hline Sugar A.F $(\mathrm{mg} / \mathrm{dL})$ & $\mathbf{1 8 3} \pm \mathbf{5 4}$ \\
\hline PMN $($ cells $/ \mathrm{mm} 3)$ & $\mathbf{3 7 1} \pm \mathbf{1 3 2}$ \\
\hline
\end{tabular}

\section{Discussion}

In Egypt, hepatic diseases, especially hepatitis $\mathrm{C}$ and $\mathrm{B}$ viruses, are currently the main causes of cirrhosis according to Perz et al., 2006. In the current study, percentages of $\mathrm{HCV}, \mathrm{HBV}$, and co-infected patients having cirrhosis are reported to be $90 \%, 2 \%$, and 3\%, respectively. These results are in agreement with those of Perz et al., 2006, Dan and Longo 2012, and Friedman 2014. In addition, our finding is consistent with Edwards and Kushner 1993 who reported that $5 \%$ of patients with hereditary hemochromatosis have cirrhosis.

PCR tests and other molecular techniques for investigation have been recognized to be the most accurate methods for detecting H. pylori (Belda et al.,
2012). PCR is a fast, cost-effective method that can be used to detect genotypes (Garza-Gonzlez et al., 2014). Moreover, it can be performed on tissue and stool specimens and is used to detect antibiotic resistance and virulence (Guarner et al., 2010). UreA gene was used in this study as a PCR target. A PCR product with amplification size of 200 bp was obtained from $75 \%$ of the ascitic fluid samples of patients with $H$. Pylori infection; this is in agreement with Hunt et al., 2010 who reported the H. Pylori to be an endemic infectious agent in Egypt with an incidence rate of $90 \%$. The results of the current study are also in agreement with $\mathbf{H e}$ et al., (2002) and Vinette et al., (2004) results who reported the ureA gene is conserved and specific to $H$. pylori. On the 
contrary, Lu et al., (1999) showed that ureA gene PCR has low sensitivity (75\%).

Ebruasicioglu et al., (2010) reported that there may be an unusual presentation of peritonitis without any white cells in the peritoneal aspirate despite multiple positive peritoneal cultures. Furthermore, they stated that immune suppression is a possible mechanism for the lack of white cells in patients with peritonitis. Furthermore, the prompt treatment with subsequent improvement of survival, detection, and identification of $H$. pylori by culture is still tricky (Runyon 2009).

Cirrhotic patients are often screened for early signs of HCC according to Singal et al., 2014. Laboratory data of all the study populations showed an elevation of bilirubin with mean $\pm \mathrm{SD}(2 \pm 1.7)$ which agrees with the findings of Friedman 2014. Inconsistency with Christou et al., 2007 study, sugar in the ascitic fluid was reported to be significantly associated with H. pylori infection $(\mathrm{P}=0.0155)$ as the exudative ascitic fluid has lower glucose level than transudatives due to the destruction or glycolysis of glucose by the action of bacteria and cells. Ascitic fluid glucose can drop significantly in severe infections like secondary peritonitis or late stage of spontaneous bacterial peritonitis.

Koss 1997 reported that specific gravity is less than 1.05 in transudative ascitic fluid and more than 1.05 in exudative ascitic fluid; this agrees with our study results that showed a significant association between $H$. pylori infection and specific gravity $(\mathrm{P}=0.0033)$. In the present study, PMN showed a highly significant association with the incidence of $H$. pylori infection $(\mathrm{P}=0.0001)$; this agrees with a previous study by Dever and Sheikh 2015 which showed that the spontaneous bacterial peritonitis requires an ascitic fluid PMN count of at least 250 cells $/ \mathrm{mm}^{3}$. According to Portillo et al., 2000, ascites with high protein content were reported in up to $25 \%$ of patients with chronic liver diseases although it is a consistent finding in malignant ascitic fluid.
Conversely, a relatively low ascites protein concentration may be found in patients with exudative ascites if there is hypoproteinemia. Spontaneous bacterial peritonitis (SBP) is often associated with low protein and high albumin gradient; this agrees with the present study data which showed a significant association of $H$. pylori infection with albumin level and SAAG $(\mathrm{P}=0.0153,0.0198$, respectively).

Diagnostic paracentesis or ascitic fluid analysis should be done for all patients with new-onset of ascites as SBP is the most frequent and fatal complication of ascites. Late or misdiagnosed SBP can lead to increased mortality. SBP is estimated to affect $10-30 \%$ of cirrhotic patients hospitalized with ascites and the percentage of mortality in this group could approach 30\% (Grabau et al., 2004). SBP diagnosis still relies on positive cultures as well as cell count of more $250 \mathrm{cell} / \mathrm{mm}^{3}$ in the peritoneal aspirate (Ebruasicioglu et al., 2010). However, a variant of peritonitis was characterized by negative ascites. This is attributed to the fact that general media is not suitable to culture bacteria of ascitic fluid and this may cause false-negative results (Runyou, 2009).

\section{Conclusion}

The current study showed an association between the incidences of $H$. pylori infection and decompensated liver cirrhosis which mainly resulted from $\mathrm{HCV}$ and HBV infections in Egyptian patients. The prognosis of liver diseases is appreciably affected by $H$. pylori infection. The incidence of $H$. pylori infection affected a number of biochemical parameters of the liver function. Further studies are recommended to emphasize the relation between $H$. pylori infection and prognosis of liver diseases.

Funding: This research was self-funded and did not receive any grants from any funding agency

\section{Compliance with ethical standards}

Conflict of interest: The authors have declared that no competing interest exists. 
Author Contributions Statement: 1: Mohamed Y. Nasr (Participated in the study design, manuscript revision) 2: Ehsan H. Hassan (Participated in samples and data collection) 3: Ghada Hassan (Participated in the study design and lab work) 4: Asmaa Ibrahim (corresponding author, participated in lab work as well as manuscript writing and revision) 5: Amal Abdel-Aziz (provided technical help, manuscript revision)

Ethical approval: The ethical board of University of Sadat City, Genetic Engineering, and Biotechnology Research Institute, Egypt approved the study. Patients included in the study were verbally informed about its aims and the collection of specimens was done after their consent was obtained.

\section{References}

Bakker AJ, Mücke M. (2007): Gammopathy interference in clinical chemistry assays: mechanisms, detection and prevention. ClinChemLabMed 45(9):1240-12.

Belda S, Saez J, Santibáñez M, Rodríguez JC, Sola-Vera J, Ruiz-García M, et al.,(2012): Relationship between bacterial load, morbidity and cagA gene in patients infected by Helicobacter pylori. Clinical Microbiology Infection.18: E251-3. pmid:22551001

Butel JS. Virology. In: Brooks GF, Carroll KC, Butel JS, Mores SA, editors (2007): Medical microbiology. New York: Mc Graw Hill .p. 367-620

Cirak, M.Y.; Akyön, Y.; Mégraud, F. (2007): Diagnosis of Helicobacter pylori. Helicobacter. 12 (1), 4-9.

Christou L, Economou M, Economou G, et al., (2007) :characteristics of ascites J Cancer Statistics , $49 ; 8-31$

Dan L, Longo et al., (2012): Harrison's principles of internal medicine (18th ed.), volume 2, P: 1-158

Dever JB and Sheikh MY. (2015): Review article: spontaneous bacterial peritonitis bacteriology, diagnosis, treatment, risk factors and prevention. Aliment Pharmacol. 41:116-131.

Ebruasicioglu, Arzukahveci, Elif Ari Bakir, et al., (2010 ): Unusual presentation of peritonitis with persistent clear aspirate, journal of medical case reports, (4) :11- 28.

Edwards, CQ; Kushner, JP (1993): "Screening for hemochromatosis". The New England Journal of Medicine. 328 (22): 616-20.

El-Zanaty F, Way A. (2009): Egypt Demographic and Health Survey (2008) . Cairo: Ministry of Health, El-Zanaty and Associates and Macro International; $p$. 431.

Esmat G, El-Bendary M, Zakarya S, Ela MA, Zalata K. (2012): Role of Helicobacter pylori in patients with HCV-related chronic hepatitis and cirrhosis with or without hepatocellular carcinoma: possible association with disease progression. J Viral Hepatology.19:473-479.

Fernández J, Gustot T. (2012): Management of bacterial infections in cirrhosis. J Hepatology. 56 Suppl 1:S1-12

Friedman LS (2014): Current medical diagnosis and treatment, Health Maintenance\& disease , 49; (5): 537-554

Garza-González E, Perez-Perez GI, MaldonadoGarza HJ, BosquesPadilla FJA (2014): A review of Helicobacter pylori diagnosis, treatment, and methods to detect eradication. World J Gastroenterology. Fev; 20(6): 1438-49. PubMed PMID: 24587620.

Grabau, CM, Crago SF, Hoff LK, etal., (2004): Performance standards for therapeutic abdominal paracentesis. Hepatology ; 40: 484-88.

Guarner J, Kalach N, Elitsur Y, Koletzko S. (2010): Helicobacter pylori diagnostic tests in children: Review of the literature from 1999 to 2009. Eur J Pediatr. 169:15-25. 
He Q, Wang JP, Osato $M$ and Lachman LB (2002):Real-time quantitative PCR for detection of Helicobacter pylori. J Clinical Microbiology 40:3720372-8.

Hunt RH, Xiao SD, Megraud F, etal., (2010):Helicobacter pylori in developing countries. World Gastroenterology Organisation Global Guidelines. human genomic DNA. Proceedings of the National Academy of Sciences of the United States of America; 91: 695- 9

Kawamata O, Yoshida H, Hirota K, Yoshida A, Kawaguchi R, Shiratori Y, Omata M.( 1996 ): Nested-polymerase chain reaction for the detection of Helicobacter pylori infection with novel primers designed by sequence analysis of urease A gene in clinically isolated bacterial strains.Biochemical and Biophysical Research Communications. Feb 6;219(1):266-272.

Koss LG, (1997): Criticism of the pap smear as adiagnostic tool in cervical cancer screening $J$ Cytologica, 41: 295- 301.

Kung HC, Hoyert DL, Xu J, Murphy SL. (2008): Deaths: final data for 2005. National Vital Statistics Reports. 56(10):1-12

Lage, A.P.; Godfroid, E.; Fauconnier, A.; Burette, A.; Butzler, J.P.;Bollen, A.; Glupczynski, Y. (1995): Diagnosis of Helicobacter pylori infection by PCR: comparison with other invasive techniques and detection of cagA gene in gastric biopsy specimens. $J$. Clinical. Microbiology. 33 (10), 2752-2756.

Light RW.(1979): Falsely high refractometric readings for the specific gravity of pleural fluid. Chest. 76:300-1

Lu, J-J.; Perng, C-L.; Shyu, R-Y.; Chen, C-H.; Lou, Q.; Chong, S.K.F.;Lee, C-H. (1999): Comparison of five PCR methods for detection of
Helicobacter pylori DNA in gastric tissues. J. Clinical. Microbiology. 37 (3), 772-774.

Merli, M., Giusto, M., Gentili, F. et al.(2010): Nutritional status: its influence on the outcome of patients undergoing liver transplantation. Liver International. 30: 208-214

Mitchell H, Katelaris P.(2016): Epidemiology, clinical impacts and current clinical management of Helicobacter pylori infection. Medical Journal Aust 10:376-380

Olson JC, Wendon JA, Kramer DJ, et al.(2011): Intensive care of the patient with cirrhosis. Hepatology. 54:1864-1872. Perz JF, Armstrong GL, Farrington LA, Hutin YJ, Bell BP ( 2006). "The contributions of hepatitis $B$ virus and hepatitis $C$ virus infections to cirrhosis $J$ Hepatology (4);512-18.

Pirouz T, Zounubi L, Keivani H, Rakhshani N, Hormazdi M.(2009): Detection of Helicobacter pylori in paraffin-embedded specimens from patients with chronic liver diseases, using the amplification method.Digestive Diseases and Sciences. 54:14561459.

Ponzetto A, Pellicano R, Leone N, Cutufia MA, Turrini F,Grigioni WF, et al.,(2000): Helicobacter infection and cirrhosis in hepatitis $\mathrm{C}$ virus carriage: is it an innocent bystander or a troublemaker? Med Hypotheses 54: 275-27711.

Portillo-Gomez L, Morrissl L, Pandaro A, (2000): rapid and efficient detection of primary liver cancer worldwide". J. Hepatology. 45 (4): 529-38.

Runyon BA (1986): "Low-protein-concentration ascitic fluid is predisposed to spontaneous bacterial peritonitis". Gastroenterology. 91 (6): 343-6.

Runyon BA, AASLD ,(2009): Practice Guidelines Committee. Management of adult patients with ascites due to cirrhosis: an update. Hepatology, 49:87. 
Sasaki, K., Tajiri , Y., Sata, M., Fujii, Y., gastric aspirates by polymerase chain reaction. Matsubara, E, Zhao, M., Shimizu, S., Toyonaga, A, Kansenshogaku Zasshi 72: 114-122. and Tanikawa, K.(1999): Helicobacter pylori in the natural environment. Scandinavian Journal of Infectious Diseases. 31: 271-279.

Vinette KM, Gibney KM, Proujansky R, Fawcett PT.( 2004): Comparison of PCR and clinical laboratory tests for diagnosing $\mathrm{H}$. pylori infection in Singal AG, Pillai A, Tiro J (2014): "Early detection, curative treatment, and survival rates for hepatocellular carcinoma surveillance in patients with cirrhosis: a meta-analysis". PLoS Medicine. 11 (4):375-382. pediatric patients. BMC Microbiology. 4:5-12.

Waluga M, Kukla M, Żorniak M, Bacik A, Kotulski R.( 2015): From the stomach to other organs: Helicobacter pylori and the liver. World $\mathrm{J}$ Hepatology.7:

Uribe R, Fujioka T, Ito A, Nishizono A, Nasu M. (1998): Sensitive detection of Helicobacter pylori in 